\title{
Micropropagation of Alibertia edulis Rich
}

\author{
Fernanda Augusta Boato da Silva, Luiz Alfredo Rodrigues Pereira, Conceição Eneida dos \\ Santos Silveira* \\ Departamento de Botânica; Universidade de Brasilia; Brasilia - DF - Brasil
}

\begin{abstract}
The aim of this work was to develop a micropropagation protocol for Alibertia edulis, a medicinal Brazilian Cerrado plant. A. edulis seeds were sterilized and germinated in water-agar. Fifteen millimeter long explants from the seedlings cultivated for 50 days were used for the multiplication in three consecutive subcultures. The cytokinin benzyladenine (BA) alone or combined with indole-3-butyric acid (IBA) was added to 1/4 MS medium. The treatments containing combinations of the BA + IBA induced more shoot proliferation than the BA alone, with the optimum concentration of $0.5 \mathrm{mg} . \mathrm{L}^{-1}$ for both growth regulators. A. edulis shoots elongated easily and the presence of growth regulators did have a positive effect on the shoot elongation. Consecutive subcultures also had a positive effect on both sprouting and shoot elongation. Activated charcoal was essential for rooting, and all rooted plants were able to acclimatize.
\end{abstract}

Key words: Cerrado, Alibertia edulis, rooting, germination, activated charcoal

\section{INTRODUCTION}

In vitro propagation techniques have been using as an alternative way to propagate the native Cerrado species, especially for economical and conservation purposes (França et al., 1995; Pinto et al., 1994; Pereira et al., 2005). Tissue culture techniques offer several possibilities for plant propagation using vegetative plant parts to induce organogenesis and plant regeneration under aseptic conditions. Among the techniques that are commonly used in plant tissue culture, micropropagation has been extensively used to rapidly propagate several species of economical interest such as Eucalyptus spp., citrus, and others (Koriesh et al., 2003; Souza et al., 2005). Micropropagation consists of vegetative propagation techniques with the purpose of obtaining plant multiplication through: a) somatic embryogenesis, b) direct or indirect (callus) de novo shoot formation, and c) induce the development of excised apical/axillary buds (Ahmed et al., 2001)

Compared with the traditional methods of vegetative plant propagation, the micropropagation has the advantage of facilitating the production of uniform and healthy plants, as well as to reduce propagation time. Furthermore, micropropagation techniques do not depend on the climatic conditions and are especially useful in species that present recalcitrant seeds, which rapidly lose their viability; it is the case of several tropical perennial species. Micropropagation is also important for long term conservation efforts to preserve the biodiversity of endangered species and ecosystems (Siddique et al., 2003).

Alibertia edulis Rich. (Rubiaceae), commonly known as quince, is a Brazilian Savanna arboreal species that reaches up to eight meters in height, with beautiful foliage and white flowers. Besides

\footnotetext{
* Author for correspondence
} 
the potential as an ornamental plant, the fruits of A. edulis are an important food source for the local population (Almeida et al., 1998). Although, the fruit has a small amount of pulp, it is very tasteful and can either be consumed fresh or in a more elaborated form as jelly. Moreover, the fruit is also part of the diet of the native Cerrado fauna (SouzaSilva and Ferreira, 2004). Also, A. edulis has been used in pharmacological studies to extract triterpene compounds from the leaves (Brochini et al., 1994), as well as substances with DNA intercalation activity from the stem (Gupta et al., 1996).

The sexual reproduction is the only known propagation form of $A$. edulis. It has been shown that the viability of the seeds decrease over time upon desiccation (Wetzel and Caldas, unpublished results). Therefore, the objective of this study was to establish a micropropagation protocol for this species using the seeds of previously selected mother plants, which helped to produce plants with outstanding qualities for medicinal, conservational and agricultural purposes.

\section{MATERIAL AND METHODS}

\section{Plant Material and Disinfestation}

Mature and healthy fruits of A. edulis were collected in November 2001 in a Cerrado forest in the vicinity of Brasilia, Brazil. The samples were cataloged and stored in the Herbarium of University of Brasilia (UB), and given the registration number UB-106.224. The seeds were manually extracted and slowly dried in the shade for eight hours to facilitate the seed separation and selection.

The seeds were disinfested in $70 \%$ ethanol for five minutes, and subsequently soaked in commercial sodium hypochlorite ( $2 \%$ active chlorine) for 15 , 30 , or 40 minutes and then rinsed with sterile distilled water. For each disinfestation treatment, two sets of 24 seeds (scarified and non-scarified) were placed on the water-agar culture medium to germinate $\left(6 \mathrm{~g} \cdot \mathrm{L}^{-1}\right)$. The number of in vitro germinating seeds was determined daily, until the $40^{\text {th }}$ day of culture. The seeds were considered germinated when the radicle emerged from the seed coat. The scarification method was mechanical and consisted of puncturing the tegument to facilitate the imbibition of the seed. The seeds and the explants were always manipulated in aseptic conditions, in a horizontal laminar flow chamber. The culture conditions in all cases were: temperature $25 \pm 2{ }^{\circ} \mathrm{C}, 80 \%$ relative humidity, $16 \mathrm{~h}$ photoperiod and light intensity of $41 \mu$ moles. $\mathrm{m}^{-2} \cdot \mathrm{s}^{-1}$.

\section{Multiplication and Subcultures}

Developing seedlings were the primary source of the explants for the multiplication experiments. The explants consisted of the aerial part of the seedlings and were approximately $15 \mathrm{~mm}$ long, measured from the top of the shoot. These explants contained the apical bud and usually the two subjacent nodes and were excised 50 days after the inoculation (DAI) of the seeds. These explants were inoculated in $1 / 4$ strength Murashige and Skoog (MS) medium (1962), pH 5.8, 30 g.. ${ }^{-1}$ sucrose, and 6.5 g.L ${ }^{-1}$ agar. The multiplication media contained 6-benzyladenine (BA; 0.0, 0.1, 0.5 , or $1.0 \mathrm{mg} . \mathrm{L}^{-1}$ ) and/or indole-3-butyric acid (IBA; $0.5 \mathrm{mg} . \mathrm{L}^{-1}$ ). The multiplication phase of this work consisted of three subcultures with six replicates/treatment.

\section{Rooting}

The rooting medium was the same used during the multiplication phase with the following modifications: 15 g. $\mathrm{L}^{-1}$ sucrose and 10 g.L $\mathrm{L}^{-1}$ of activated charcoal (Sigma Chemical CO.). Six elongated shoots from each treatment (6 treatments) of the third multiplication subculture were put to root in three different concentrations of IBA $\left(0.0 \mathrm{mg} . \mathrm{L}^{-1}, 0.01\right.$ and $\left.0.1 \mathrm{mg} . \mathrm{L}^{-1}\right)$. The shoots from the two control multiplication treatments $\left(0.0 \mathrm{mg} . \mathrm{L}^{-1} \mathrm{IBA}+0.0 \mathrm{BAP} \mathrm{mg} \cdot \mathrm{L}^{-1}\right.$ and $\left.0.5 \mathrm{mg} . \mathrm{L}^{-1} \mathrm{IBA}+0.0 \mathrm{BA} \mathrm{mg} \cdot \mathrm{L}^{-1}\right)$ were not used for the rooting. The explants $(n=6)$ from one specific multiplication treatment were distributed in the three rooting treatment (two per treatment) to evaluate the effect of the multiplication treatment on the rooting. Therefore, there were 12 explants per rooting treatment. The percentage of rooted plants was determined at the $30^{\text {th }}$ and $60^{\text {th }}$ days of the culture.

\section{Acclimatization}

All the rooted plantlets were transferred to plastic pots containing sterile vermiculite, covered by transparent plastic bags to maintain a high humidity environment for the acclimatization. The plantlets were kept the under natural illumination in a shaded place. As the leaves expanded, the bags were gradually opened, allowing the plants to adapt to a drier environmental condition. At the 
third week of acclimatization, the plants were fertilized with MS nutrient solution. After eight weeks, the acclimatized plants were transferred to peat-based growing media and vermiculite (1:1, w/w) and kept in this substrate for 60 days, after which they were transferred to the Cerrado soil.

\section{Statistical Analysis}

The data were statistically analyzed by two way ANOVA and the differences between the means were tested by the Student's T-test $(p=0.01)$. The results were expressed as the average of the shoot sprouts/explants or shoot length/treatment \pm standard error (SE).

\section{RESULTS}

All the steps for the micropropagation of A. edulis were successful (Fig. 1a-g). In general, the seeds produced healthy and vigorous seedlings (Fig. 1ab), which allowed the establishment of a propagation protocol for this species.

\section{Disinfestation, Germination and Seedling Development}

All the disinfestation treatments were effective to prevent the contamination ( $0 \%$ contamination) and did not affect the germination capacity of the seeds, which showed a high germination rate (above $85 \%$, Table 1). In all the treatments, the seeds started to germinate around the $12-13^{\text {th }}$ DAI and most of the seeds had already germinated by the $30^{\text {th }}$ DAI. As shown in Table 1, the germination was completed between 25-40 DAI, with the germination percentage varying from 88 to $100 \%$. At the $50^{\text {th }}$ day after the inoculation, there was no statistically significant difference in germination percentage between the scarified and non-scarified seeds $(\mathrm{p}=0.01)$. Furthermore, the rate of the germination of the scarified and nonscarified treatments appeared to be similar, however, the scarified seeds tended to take a little longer to reach $100 \%$ germination (Table 1).

Table 1 - Effect of the time of disinfestation in $2 \%$ sodium hypochlorite and scarification on the germination of $A$. edulis.

\begin{tabular}{|c|c|c|c|c|c|c|}
\hline \multirow{2}{*}{$\begin{array}{l}\text { Days after } \\
\text { inoculation }\end{array}$} & \multicolumn{3}{|c|}{ Germination of non-scarified seeds (\%) } & \multicolumn{3}{|c|}{ Germination of non-scarified seeds (\%) } \\
\hline & $15 \mathrm{~min}$ & $30 \mathrm{~min}$ & $40 \mathrm{~min}$ & $15 \mathrm{~min}$ & $30 \mathrm{~min}$ & $40 \mathrm{~min}$ \\
\hline $0-5$ & 0 & 0 & 0 & 0 & 0 & 0 \\
\hline $6-10$ & 0 & 0 & 0 & 0 & 0 & 0 \\
\hline $11-15$ & 67 & 75 & 67 & 67 & 63 & 75 \\
\hline $16-20$ & 63 & 75 & 67 & 67 & 63 & 75 \\
\hline $21-25$ & 67 & 88 & 75 & 79 & 71 & 75 \\
\hline $26-30$ & 83 & 100 & 88 & 92 & 88 & 83 \\
\hline $31-35$ & 100 & 100 & 88 & 92 & 100 & 92 \\
\hline $36-40$ & 100 & 100 & 88 & 92 & 100 & 92 \\
\hline $41-45$ & 100 & 100 & 88 & 92 & 100 & 92 \\
\hline $45-50$ & 100 & 100 & 88 & 92 & 100 & 92 \\
\hline
\end{tabular}

The seedlings were grown until the $50^{\text {th }}$ DAI, in order to select those with a minimum height of 15 $\mathrm{mm}$ to excise the explants. The average length of the aerial part of the seedlings was $15.1( \pm 1.3)$ $\mathrm{mm}$. The seedling development was less uniform after the $30^{\text {th }}$ DAI. Around the $50^{\text {th }}$ DAI, the seedlings presented a pair of eophylls, as well as a root system composed of tap and lateral roots. After the $60^{\text {th }}$ DAI, the seedlings started to show chlorosis and necrosis, probably due to the depletion of the culture media.

\section{Multiplication and Elongation Sprouting}

As mentioned previously, $15 \mathrm{~mm}$ long explants containing their respective apical bud, eophils and cotyledons were transferred to the multiplication media containing either BA alone or combined with IBA. In general, the treatments with BA alone were not highly effective in inducing the sprouting as seen in Fig. 2 (a-c). In the subculture 1, 0.1 and $0.5 \mathrm{mg} . \mathrm{L}^{-1}$ BA were the most effective concentrations to induce shoot formation, which 
resulted in the production of 1.8 and 2.0 sprouts/explant, respectively (Fig. 2a, and c). Moreover, $1.0 \mathrm{mg} . \mathrm{L}^{-1} \mathrm{BA}$ had no effect on sprouting when compared with the control $(0.0$ mg. $\left.L^{-1}\right)$, and both had an average around 0.4 sprout/explant (Fig. 2a and c).

As observed in the first subculture, the second and third subcultures BA did not have much effect on the sprouting (Figs. 1c, 2a, and 2c). In both subcultures, only $0.1 \mathrm{mg} . \mathrm{L}^{-1}$ BA was more effective in induction new sprouts, with an average varying around 1.8 sprout/explant in each subculture. The other BA concentrations of the subcultures 2 and 3 were incapable of significantly inducing the sprouting in comparison with the control (Fig. 2c). Basically, the treatments containing BA at the concentrations of $0.5 \mathrm{mg} . \mathrm{L}^{-1}$ and $1.0 \mathrm{mg} . \mathrm{L}^{-1}$ produced less than 0.3 sprout/explant in the subcultures 2 and 3 (Fig. 2c).

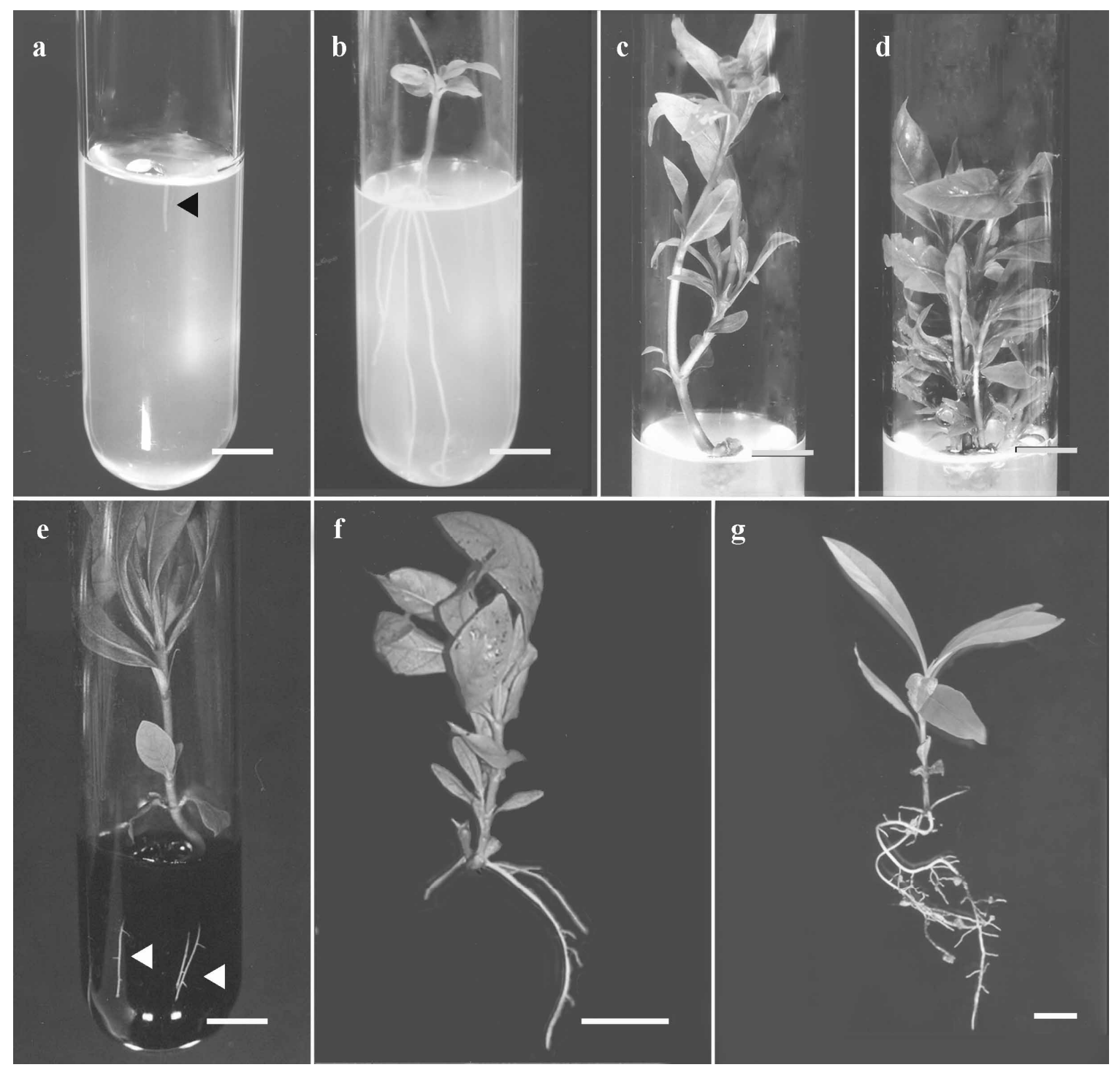

Figure 1 - Micropropagation of A. edulis. a) Recently germinated seed. Note the root (arrow) growing into the culture medium; b) Fifty-DAI seedling used to obtain the explants for the multiplication phase. Seed coat (arrow). c) Sprouted explant in $0.5 \mathrm{mg} . \mathrm{L}^{-1} \mathrm{BA} 1 / 4 \mathrm{MS}$ medium cultivated for 50 days; d) Sprouted explant in $0.5 \mathrm{mg} . \mathrm{L}^{-1} \mathrm{BA}+0.5 \mathrm{mg} . \mathrm{L}^{-1} \mathrm{IBA} 1 / 4$ MS medium after 50 days of cultivation. e) Rooted plantlet in $1 / 4$ MS medium plus activated charcoal and $0.01 \mathrm{mg} . \mathrm{L}^{-1}$ IBA. Observe the developing roots (arrows). f) Rooted plantlet before the acclimatization phase. g) Acclimatized plantlet. Abbreviation: DAI days after inoculation. Scale bar $=1 \mathrm{~cm}$. 
The treatments containing the combinations of BA + IBA presented the best results in terms of shoot the formation (Figs. 1d, 2b, and 2c). In all three subcultures with BA + IBA there was an increase in the number of the sprouts in the treatments containing $0.1 \mathrm{mg} . \mathrm{L}^{-1}$ and $0.5 \mathrm{mg} . \mathrm{L}^{-1} \mathrm{BA}+0.5$ mg. $L^{-1}$ IBA, after which a drop in the number of new shoots occurred (Fig. $2 b$, and c). In fact, 0.5 BA mg. $\mathrm{L}^{-1}+0.5 \mathrm{mg} . \mathrm{L}^{-1}$ IBA was the optimum combination of growth regulators in all three subcultures. Furthermore, sprouting was found to be higher in the treatments containing $0.5 \mathrm{mg} . \mathrm{L}^{-1}$ $\mathrm{BA}+0.5 \mathrm{mg} \cdot \mathrm{L}^{-1}$ and $1.0 \mathrm{mg} \cdot \mathrm{L}^{-1} \mathrm{BA}+0.5 \mathrm{mg} \cdot \mathrm{L}^{-1}$ of the subculture 3 (Fig. 2b), which had the highest number of sprouts/explant. Compared with 0.5 mg. $\mathrm{L}^{-1} \mathrm{BA}+0.5 \mathrm{mg} \cdot \mathrm{L}^{-1} \mathrm{IBA}$, the drop in the number of sprouts/explant observed with the combination $1.0 \mathrm{mg} . \mathrm{L}^{-1} \mathrm{BA}+0.5 \mathrm{mg} \cdot \mathrm{L}^{-1}$ IBA was consistent and repeated in all three subcultures (Fig. 2b). In subculture 1 this decrease in sprout formation was very subtle, and became greater in the subsequent subcultures (Figs. 2a and b). Nonetheless, $1.0 \mathrm{mg} . \mathrm{L}^{-1} \mathrm{BA}+0.5 \mathrm{mg} . \mathrm{L}^{-1} \mathrm{IBA}$ was still one of the most effective treatments in inducing the sprouting (Fig. 2a, and b).

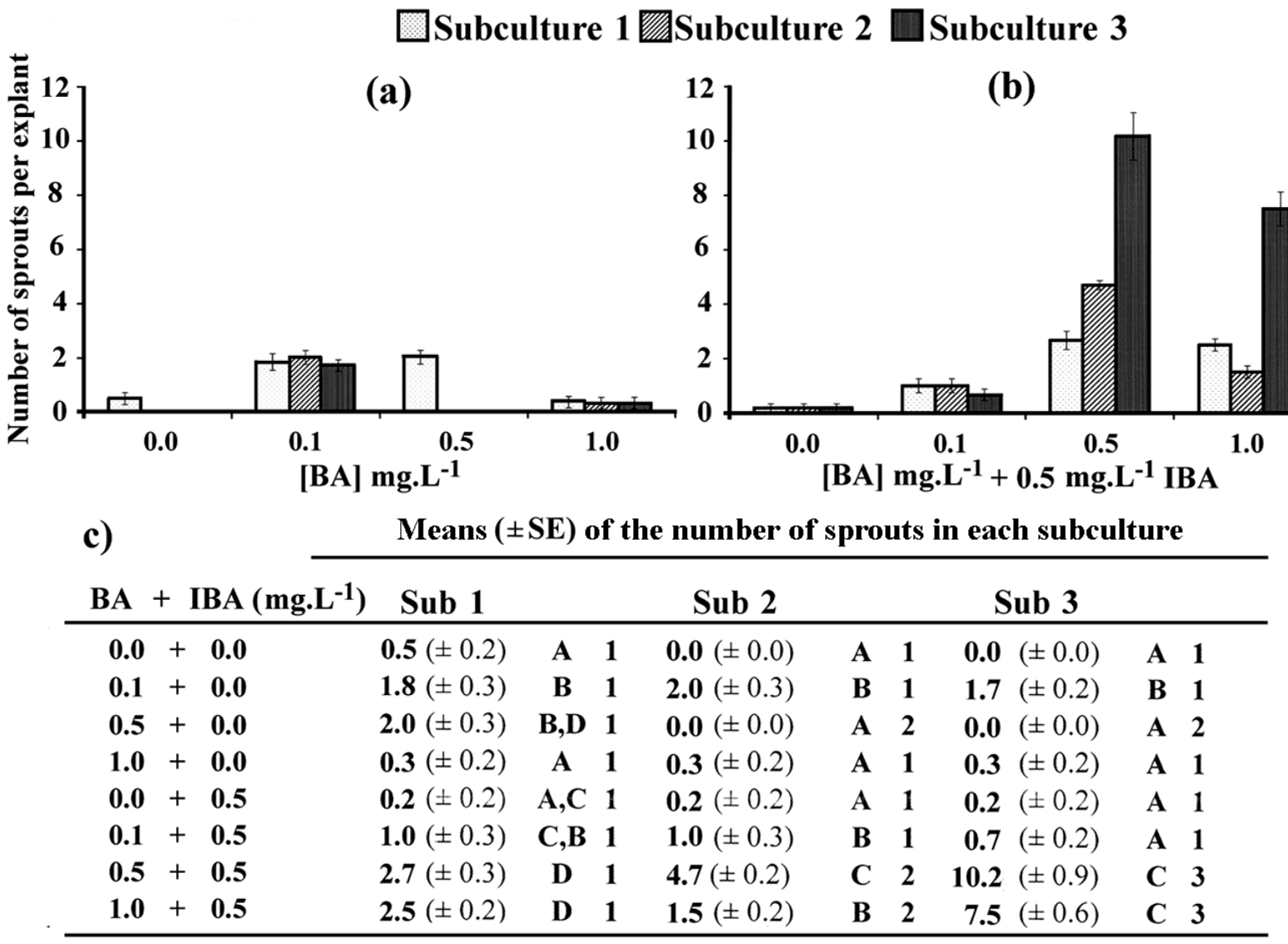

Figure 2 - Multiplication of $A$. edulis. a) Effect of BA treatments on sprouting during each subculture; b) Effect of BA + IBA concentrations on the sprouting during the subcultures; c) Means ( \pm $\mathrm{SE}$ ) of sprout/explant for each subculture. The data represent the means of six replicates per treatment. The letters compare the results only within the same subculture (column), while the numbers compare the treatments among the subcultures (rows). Results followed by the same letters or numbers, within the same column or row, are statistically similar as calculated by the Student's T-test $(\mathrm{p}=0.01)$. 


\section{Shoot length}

A. edulis shoots elongated readily even without the growth regulators although the presence of either $\mathrm{BA}$ or BA + IBA in the media positively affected the shoot growth compared with the respective controls in all subcultures (Fig. 3a-c). Moreover, within the same subculture, increasing concentrations of BA induced an increase in the shoot length up to $0.5 \mathrm{mg} \cdot \mathrm{L}^{-1}$, after which a drop in the shoot length was observed at $1.0 \mathrm{mg} . \mathrm{L}^{-1}$ in the first and second subcultures. With respect to the $\mathrm{BA}+\mathrm{IBA}$ treatments, a similar trend was observed and a small peak for the shoot length was observed at $0.5 \mathrm{mg} . \mathrm{L}-1 \mathrm{BA}+0.5 \mathrm{mg} \cdot \mathrm{L}^{-1}$ IBA $(4.8$ $\pm 0.1 \mathrm{~cm}$ and $5.0 \pm 0.2 \mathrm{~cm}$; subculture 2 and 3 , respectively; Fig. 3c). Furthermore, it appeared that the effect of the growth regulators was proportionally enhanced with the subculture (Fig. 3a-c). This subculture effect was observed for all the growth regulator concentrations, however, it was more pronounced in the treatments containing combinations of BA and IBA (Fig. 3c). Consequently, the shoot length averages in the first subculture were always the lowest for all the growth regulators concentrations, generally around $3.5 \mathrm{~cm}$ for both BA and BA + IBA treatments (Fig. 3a-c). There was some variability in the shoot length between the subcultures 2 and 3, but most were not significant (Fig. 3c). In fact, for most growth regulator concentrations used in this study, there was a trend to reach a plateau during subcultures 2 and 3 around $4.6 \mathrm{~cm}$. Additionally, in most of the cases, there were no significant differences between the shoot length of subculture 2 and 3, suggesting that the shoot elongation might have reached a maximum (Fig. 3c).

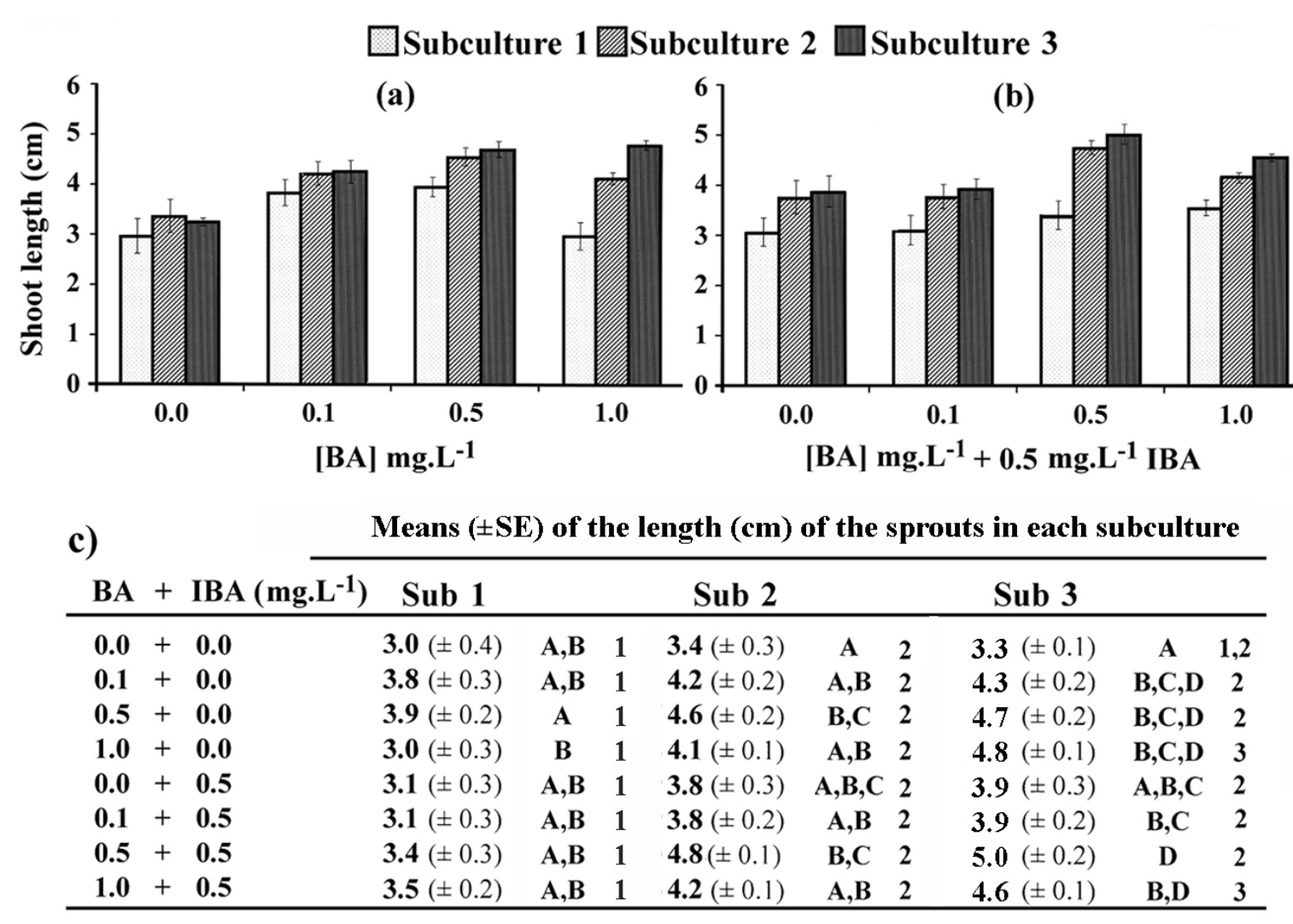

Figure 3 - Elongation of A. edulis shoots. a) Effect of BA on the shoot elongation during subcultures; b) Effect of BA + IBA concentrations on shoot elongation during the subcultures; c) Means ( \pm SE) of elongated shoots for each subculture. The data represents the means of six replicates per treatment. The letters compare the results only within the same subculture (column), while the numbers compare the treatments among the subcultures (rows). Results followed by the same letters or numbers, within the same column or row, are statistically similar as calculated by the Student's T-test $(\mathrm{p}=0.01)$. 


\section{Rooting}

Preliminary tests showed that the activated charcoal was required to induce the rooting. Surprisingly, the addition of an auxin to the culture medium was not essential for the rooting. However, 0.01 mg. $\mathrm{L}^{-1}$ IBA accelerated and synchronized the rooting process compared with the control treatment $\left(0.0 \mathrm{mg} \cdot \mathrm{L}^{-1}\right)$. Thereby, the root differentiation was not observed in the control treatment at the $30^{\text {th }}$ day of the culture, while $61 \%$ of the shoots in the medium containing $0.01 \mathrm{mg} . \mathrm{L}^{-}$

${ }^{1}$ IBA had already rooted. However, a ten-fold increase in the concentration of IBA to $0.1 \mathrm{mg} . \mathrm{L}^{-1}$ resulted in a decrease of the percentage of rooted shoots to $39 \%$ in the same period of time. Neither 0.01 nor $0.1 \mathrm{mg} . \mathrm{L}^{-1} \mathrm{IBA}$ induced callus formation at the base of the stems during rooting. After 60 days, $100 \%$ of the shoots in all the treatments had rooted (Fig. 1e).

Apparently, there was no effect of the multiplication medium (BA; BA + IBA) on the rooting capacity of the explants or on the time of rooting.

\section{Acclimatization}

Thirty five rooted shoots were acclimatized. Some morphological aspects of the explants/plantlets facilitated the acclimatization process. Although all A. edulis plantlets acclimatized quite well, those originated from explants with homogenous and healthy green leaves, no detectable chlorosis, well developed root systems, and no callus formation at the junction of stems/roots normally acclimatized much faster. After the transfer to vermiculite all the 35 rooted plantlets survived, producing at least one new pair of leaves at the end of four weeks (Fig. 1f and g). The acclimatized plants developed well for the next two months, after which the plants continued to develop at a slower rate.

\section{DISCUSSION}

The establishment of the propagation protocols is extremely important for the preservation of Brazilian Savanna, also known as Cerrado. The vegetation of this extensive ecosystem has been gradually and consistently devastated by the agricultural activities such as pasture formation and culture of soybean, corn and cotton (Moffat, 2002). This shows the importance and urgency of establishing the proper means to preserve the plant species occurring in this biome, many of which are still unknown.

Several steps are crucial to establish an in vitro propagation protocol. Initially, it is necessary to develop a disinfestation methodology that will permit the cultivation of plant parts and allow them to grow free of exogenous and/or endogenous microorganisms. The substances with germicide activity such as alcohol and sodium hypochlorite have been routinely used to disinfest plant parts used in tissue culture. It is well known that most of the time, the seeds are less contaminated than other plant parts collected from the specimens in the field, and they are normally more resistant to the harshness of the disinfestation treatments (Melo et al., 1998). Therefore, in this study the seeds were germinated to provide the plant explants necessary to develop a vegetative propagation method for A. edulis.

In Cerrado plants such as Kielmeyera coriacea (Arello and Pinto, 1993) the seeds could be disinfested by rinsing them in $70 \%$ ethanol, followed by a soaking step in a commercial sodium hypochlorite solution ( 0.2 to $2 \%$ active chlorine) for five min, with a subsequent wash in sterile water. A protocol based on these procedures worked well for A. edulis seeds. In this case, the only difference was the soaking time in $2 \%$ bleach that varied from 15 to $40 \mathrm{~min}$ for A. edulis. All the disinfestation treatments were effective to prevent the contamination, which indicated that the tested disinfestation times were adequate to obtain the aseptic culture of A. edulis seeds. In addition, the tested disinfestation times did not affect the germination capacity of the seeds (Table 1).

Bewley and Black (1994) defined germination as the process that commenced with the uptake of the water by the dry seed and terminated with the elongation of the embryonic axis, usually the radicle. Thus, in this study the germination was concluded with the emergence of the radicle. In $A$. edulis, the in vitro germination was not highly synchronized and varied from 10 to 30 days. This is usually expected in species that have not been subjected to domestication for agricultural purposes, and did not appear to be associated with the seed coat dormancy as shown by the scarification tests.

The scarification can be accomplished by chemical, mechanical, and thermal methods (Barbosa et al., 2005). It is known to increase the efficiency and speed of the germination by breaking the dormancy associated with the seed 
coat and also helps to synchronize the germination by facilitating water uptake (Malavasi and Malavasi, 2004; Barbosa et al., 2005). Once the seeds are scarified, water is absorbed initiating imbibition, which triggers other physiological and biochemical events resulting in the germination. Therefore, it was expected that the scarified seeds would germinate earlier and in a more synchronized pattern. Nevertheless, the scarification did not dramatically change the germination pattern of A. edulis seeds. In fact, the scarified seeds took a little longer to reach $100 \%$ germination compared with non-scarified seeds. The data suggested that the initiation of the germination process may be controlled by endogenous factors. If this is true, this endogenous regulation of germination could be part of a plant strategy to assure the success of the reproductive cycle (Melo et al., 1998; Eira and Caldas, 2000). Some plant species use environmental cues, such as drought, rainfall, temperature, and fire to synchronize the germination of the majority of the seeds at a particular time, while other species have an asynchronous germination pattern over an extended time (Eira and Caldas, 2000; Godoi and Takaki, 2004; Hölzel and Otte, 2004). Therefore, the lack of the dormancy associated with the seed coat together with the asynchronism of $A$. edulis seed germination could indicate an endogenous control of germination as a surviving strategy, which is not unusual in Cerrado plant species (Melo et al., 1998).

\section{BA + IBA Combinations Resulted in Higher Multiplication of A. edulis Shoots}

For the multiplication, $15 \mathrm{~mm}$ long explants from the seedlings of $A$. edulis were inoculated in $1 / 4 \mathrm{MS}$ medium. In general, diluted MS media have been successfully used for explant multiplication in plant tissue culture. The dilution of macro and micronutrients of MS medium may favor several morphogenetic events in many plant species, which was also observed in the micropropagation of Stryphnodendron polyphythum (França et al., 1995), multiplication of Kielmeyera coriacea (Pinto et al., 1994) and Acacia mearnii (Quoirin et al., 2002).

Another important aspect for the multiplication is the presence of plant growth regulators in the medium. In general, the presence of BA did not greatly increase the sprouting in A. edulis explants as expected based on the role of cytokinins in the release the apical dominance. BA induced the sprouting in all treatments only in subculture 1 with a peak between 0.1 and $0.5 \mathrm{mg} \cdot \mathrm{L}^{-1}$, while in the other subcultures its effect was more pronounced only at $0.1 \mathrm{mg} . \mathrm{L}^{-1}$. The importance of auxin and cytokinin balance has been reported in regulating the apical dominance as well as in a number of morphogenetic events such as shoot formation and branching ( $\mathrm{Li}$ and Bangerth, 2003; Werner et al., 2003; Nakagawa et al., 2005). Another factor that may influence the morphogenetic events during in vitro culture is a possible interaction between the endogenous concentrations of plant growth regulators and those present in the culture medium (Pinto et al., 1994; Mercier et al., 2003). As concentrations around $0.1 \mathrm{mg} . \mathrm{L}^{-1} \mathrm{BA}$ favored the sprouting in all three subcultures, this could be the optimum BA concentration for a cytokinin and endogenous auxin balance that resulted in release of the apical dominance in the culture conditions. It was also noteworthy that all explants of the first subculture had the apical bud. Apical meristems have been reported as auxin producer centers (Nakagawa et al., 2005), therefore a higher content of the endogenous auxin could explain the extended effect of BA (0.1 and $0.5 \mathrm{mg} . \mathrm{L}^{-1}$, see Fig. 2a and 2c) during the subculture 1 . On the other hand, BA concentrations higher than $0.1 \mathrm{mg} . \mathrm{L}^{-1}$ and 0.5 $\mathrm{mg} . \mathrm{L}^{-1}$ (only for subculture 1 ) had no effect on the sprouting process, which suggested that these concentrations of the exogenous cytokinin might be beyond the ideal auxin/cytokinin ratio in terms of sprouting.

The data showed that the combination of auxin and cytokinin resulted in higher production of new shoots in all three subcultures in comparison with the treatments with BA alone (Fig. $2 b$ and c). Hence, the combinations of auxin and cytokinin at a particular range of concentrations could increase the efficiency of shoot production in A. edulis explants as observed for other Cerrado species such as Kielmeyera coriacea (Arello and Pinto, 1993). These results reinforced the hypothesis that in vitro shoot proliferation could be more efficient with the application of two or more classes of growth regulators.

For sprout induction in A. edulis explants, the optimum BA + IBA combination was $0.5 \mathrm{mg} \cdot \mathrm{L}^{-1}+$ $0.5 \mathrm{mg} . \mathrm{L}^{-1}$. This combination resulted in the production of approximately 10 sprouts/explant in the third subculture, which suggests that the number of subcultures could have an important effect on the shoot induction. This subcultural 
effect was likely associated with a more appropriate balance between the endogenous and exogenous plant growth regulators for the sprouting as the explants were subcultured. From one subculture to another the content of the endogenous plant growth regulators may decrease and the combinations of exogenous growth regulators in the culture medium can be more effective during the multiplication phase.

\section{There Was No Need for Auxin/Cytokinin Supplementation for A. Edulis Shoot Elongation}

As observed during the multiplication phase, two things should be considered during $A$. edulis shoot elongation: first, the effect of the growth regulators on the elongation of $A$. edulis shoots, and second, the effect of the subcultures. Although the presence of the growth regulators was not a sine qua non condition for A. edulis elongation, the addition of auxin and/or cytokinin did promote higher elongation of the explants compared with the respective control treatments. Nevertheless, this positive effect on the shoot length was not growth regulator-specific. Hence, BA alone and combined with IBA had similar effects on elongation.

It is well documented that auxins, gibberellins and polyamines usually favor shoot elongation (Little and MacDonald, 2003; Nuri, 2004), while cytokinins may act in a different manner and favor shoot sprouting (Perez-Tronero et al., 2000). However, the effects of these classes of plant growth regulator are not always the same and depend on variables such as the plant species, the type and the concentrations of the growth regulators, and growth conditions. Thus, it is not unusual to find cytokinins promoting shoot elongation such as in Balanites aegyptiaca (Ndoye et al., 2003), Lingonberry (Debnath, 2005), and Averrhoa carambola (Khalekuzzaman, 2003). Similarly, auxin instead of promoting the elongation may inhibit the shoot elongation in some species, such as Brassica napus (Khan et al., 2002). In addition, the combination of auxin and cytokinin can also act in synergism and promote shoot elongation (Anis et al., 2005). Therefore, the effects of the growth regulators can be quite variable, not always following the classical patterns, and shoot elongation in A. edulis appears to support this.

Furthermore, it is interesting to note that the effect of BA treatments followed a pattern a bit different than that in combination with IBA (Figs. 3a and $3 b)$. While the shoots in the BA treatments showed increasing elongation with the increase in concentration up to $0.5 \mathrm{mg} . \mathrm{L}^{-1}$, in $\mathrm{BA}+$ IBA the maximum elongation was observed between 0.5 mg. $\mathrm{L}^{-1} \mathrm{BA}+0.5 \mathrm{mg} . \mathrm{L}^{-1} \mathrm{IBA}$ and $1.0 \mathrm{mg} \cdot \mathrm{L}^{-1} \mathrm{BA}+$ 0.5 mg. $\mathrm{L}^{-1}$ IBA. The data indicated that a concentration around $0.5-1.0 \mathrm{mg} . \mathrm{L}^{-1}$ of $\mathrm{BA}$ or combined with IBA could be the most appropriate for A. edulis shoot elongation.

With respect to the subcultural effect on the shoot elongation, it was noteworthy that the elongation stabilized after the second subculture (Fig. 3a-c). Moreover, this subcultural effect seemed to be magnified by the presence of growth regulators in the culture medium, having an optimum combination of $0.5 \mathrm{mg} . \mathrm{L}^{-1} \mathrm{BA}+0.5 \mathrm{mg} . \mathrm{L}^{-1} \mathrm{IBA}$ around the second/third subcultures (Figs. $3 \mathrm{~b}$ and $3 c)$. The endogenous concentrations of the plant growth regulators were also likely involved in this subcultural effect on the elongation. As the explants were subcultured, the endogenous growth regulators tended to reach equilibrium with those present in the culture medium resulting in a more effective morphogenetic response to the exogenous growth regulators added to the medium.

The fact that $A$. edulis shoots sprouted and elongated (with or without growth regulators) quite well paved the road to the rooting phase.

\section{Rooting of A. edulis Explants Required Activated Charcoal}

For the establishment of a successful micropropagation protocol, it is necessary that the explants are able to root. Normally, the shoots that do not elongate adequately have low rooting capacity, and require an extra elongation step before rooting (Grattapaglia and Machado, 1998). Therefore, as A. edulis shoots elongated well on the multiplication medium they did not need a specific elongation phase previously to rooting.

The presence of activated charcoal was necessary for the rooting. Activated charcoal has many effects on the plant tissue response. For the rooting process, it provides a dark environment that may facilitate root differentiation. In general, auxin induces the formation of adventitious roots and the activated charcoal contributes to prevent the photodegradation of auxin (Epstein and LudwigMüller, 1993; Pan and Staden, 1998). Moreover, activated charcoal acts as a chelator for many compounds, including plant for the growth 
regulators. This substance is able to adsorb auxins such as IBA (for review see Pan and Staden, 1998). Although auxin may be necessary for the rooting, roots are extremely sensitive to this class of plant growth regulator, which in concentrations above the optimum becomes toxic. Hence, it helps to decrease the toxicity of auxins, in case their concentrations in the culture medium are overestimated. The results showed that the presence of the exogenous auxin was not limiting for A. edulis rooting. However, the dark environment provided by the activated charcoal was essential to induce in vitro root formation in this species.

Although all the explants rooted after 60 days, $0.01 \mathrm{mg} \cdot \mathrm{L}^{-1}$ IBA induced a faster root differentiation than the other treatments. This concentration was likely within the optimum range for inducing the root in A. edulis. The exogenous auxins have been found to enhance the rooting in many Cerrado native species either in vitro (Almeida and Shepherd, 1999) or by cuttings (Rios et al., 2001). On the other hand, $0.1 \mathrm{mg} . \mathrm{L}^{-1}$ appeared to be excessive but not toxic, resulting in a slower formation of adventitious roots. However, the callus formation at the base of the explant was not observed as would be expected with high levels of the exogenous auxin. This indicated that even beyond the optimum range A. edulis was tolerant to higher auxin levels and still rooted adequately. In fact, the lack of the callus formation might have favored the acclimatization of the plantlets, due to a direct vascular connection between the adventitious roots and stems, as observed in Fraxinus excelsior (Silveira and Cottignies, 1994). Therefore, the high rate of the rooted plantlet acclimatization (100\%) observed in A. edulis could suggest a good integration of the root/stem vascular systems. Additionally, the plantlets had well developed green leaves, which certainly helped during the acclimatization allowing the plants to become autotrophic organisms more rapidly (Grattapaglia and Machado, 1998).

The micropropagation protocol established here could have commercial and conservational applications. Based on that, A. edulis mother plants could be propagated to facilitate the agricultural and pharmacological use of this species. Also, this protocol provided the means to rapidly produce plants for recuperating the degraded areas with the native flora.

\section{ACKNOWLEDGEMENTS}

We would like to thank Dr Linda Styer Caldas for her valuable suggestions and help with the English version of this work. Also, we thank Dr José Elias de Paula for helping during the collection and identifying the botanical material. We also want to mention Elias Cavalcante for the technical support. Special thanks to the Brazilian Council of Research (CNPq) for sponsoring this study.

\section{RESUMO}

Foi desenvolvido um protocolo de micropropagação para A. edulis, uma espécie arbórea frutífera e medicinal presente no Cerrado brasileiro. Sementes de A. edulis foram esterilizadas e germinadas em ágar-água. Explantes de $15 \mathrm{~mm}$ foram retirados das plântulas e cultivados por 50 dias em meio de multiplicação e três subculturas. A citocinina benzilalanina (BA), sozinha ou em combinação com ácido indol butírico (IBA) foram adicionados em no meio 1/4 MS. Os tratamentos contendo combinações de BA-IBA induziram uma maior proliferação de brotos que aqueles somente com BA, e a concentração ótima desses reguladores de crescimento foi de $0.5 \mathrm{mg} . \mathrm{L}^{-1}$ para cada. Os brotos de A. edulis facilmente se alongaram e a presença de reguladores de crescimento no meio de cultura teve efeito positivo sobre o alongamento. Da mesma forma, as consecutivas subculturas tiveram um efeito positivo tanto sobre a brotação quanto no alongamento. Carvão ativado foi essencial para o enraizamento dos ramos, e todas as plantas foram aclimatadas com sucesso.

\section{REFERENCES}

Ahmed, Z., Akhter, F., Haque, M. S., Banu, H., Rahman, M. M., Faruquzzaman, A. K. M. (2001), Novel micropropagation system. J. Biol. Sci., 11, 1106-1111.

Almeida, S. P., Proença, C.E. B., Sano, S. M., Ribeiro, J. F. (1998), Cerrado: espécies vegetais úteis. EMBRAPA, Brasília.

Almeida, V. P., Shepherd, S. L. K, (1999), Sinningia allagophylla (Gesneriaceae): in vitro cultivation of a native plant of the Brazilian Cerrado. Rev. Brasil. Bot., 22, 381-384. 
Anis, M., Husain, M. K., Shahzad, A. (2005), In vitro plantlet regeneration of Pterocarpus marsupium Roxb., an endangered leguminous tree. Curr .Sci., 88, 861-863.

Arello, E. F., Pinto, J. E. B. P. (1993), Propagação in vitro de Kielmeyera coriacea - Efeito das diversas concentrações combinadas de benzilaminopurina e ácido naftalenoacético na multiplicação de brotos. Pesq. Agropec. Bras., 28, 25-31.

Barbosa, J. G., Alvarenga, E. M., Fernandes, D. C. S. D., Vieira, A. N. (2005), Efeito da escarificação ácida e de diferentes temperaturas na qualidade fisiológica de sementes de Strelitzia regina. Rev. Bras. Sem., 27, 71-77.

Bewley, J. D., Black, M. (1994), Seeds: physiology of development and germination. $2^{\text {nd }}$ ed. Plenum Press, New York, 445p.

Brochini, C. B., Martins, D., Roque, N. F. (1994), An oleanane acid form Alibertia edulis. Phytochemistry, 36, 1291-1295.

Debnath, S. C. (2005), A Two-step procedure for adventitious shoot regeneration from in vitro-derived Lingonberry leaves, shoot induction with TDZ and shoot elongation using zeatin. HortScience, 40, 189192.

Eira, M. T. S., Caldas L. S. (2000), Seed dormancy and germination as concurrent processes. Braz. J. Plant Physiol., 12,85-104.

Epstein E., Ludwig-Müller J. (1993), Indole-3-butyric acid in plants: occurrence, synthesis, metabolism and transport. Physiologia Plantarum 88, 382-389.

França, S. C., Duarte, I. B., Moraes, R. M., Pereira, A. M. S. (1995), Micropropagation of Stryphnodendron polyphythum (Barbatimão). Plant Cell Tissue Organ Cult., 42, 291-293.

Godoi, S., Takaki, M. (2004), Effects of light and temperature on seed germination in Cecropia hololeuca Miq. (Cecropiaceae). Braz. Arch. Biol. Tech., 47, 185-191.

Grattapaglia, D., Machado, M. A. (1998), Micropropagação. In Cultura de tecidos e transformação genética de plantas. Ed Torres AC, Caldas LS, Buso JA. Vol 1. EMBRAPA - Brasilia, pp. 183-260.

Gupta, M. P., Monge, A., Karikas, G. A., deCerain, A. L., Solis, P. N., deLeon E., Trujillo, M., Suarez, O., Wilson, F., Montenegro, G., Noriega, Y., Santana, A. I., Correa, M., Sanchez, C. (1996), Screening of Panamanian medicinal plants for brine shrimp toxicity, crown gall tumor inhibition, cytotoxicity and DNA intercalation. Int. J. Pharm., 34, 19-27.

Hölzel, N., Otte, A. (2004), Ecological significance of seed germination characteristics in flood-meadow species. Flora, 199, 12-24.

Khalekuzzaman, M., Alam, M. F., Nuruzzaman, M., Begum, N., Ahmed, M. G., Islam, M. A., Joarder, O. I. (2003), Clonal propagation of Averrhoa carambola linn. through nodal culture of mature tree. J. Biol. Sci., 3, 1153-1157.

Khan, M. R., Rashid, H., Quraishi, A. (2002), Effects of various growth regulators on callus formation and regeneration in Brassica napus Cv. oscar. Pakistan J. Biol. Sci., 5, 693-695.

Koriesh, E. M., Abd El-Fattah, Y. M., El-Dayem, M. A., El-Etriby, M. A. (2003), Micropropagation of juvenile Eucalyptus citriodora. Acta Hort., 625, 283288.

Li, C., Bangerth, F. (2003), Stimulatory effect of cytokinins and interaction with IAA on the release of lateral buds of pea plants from apical dominance. J. Plant Physiol., 160, 1059-1063.

Little, C. H. A., MacDonald, J. E. (2003), Effects of exogenous gibberellin and auxin on shoot elongation and vegetative bud development in seedlings of Pinus sylvestris and Picea glauca. Tree Physiology, 23, 7383.

Malavasi, U. C., Malavasi, M. M. (2004), Dormancy breaking and germination of Enterolobium contortisiliquum (Vell.) Morong seed. Braz. Arch. Biol. Tech., 47, 851-854.

Melo, J. T., Silva, J. A., Torres, R. A. A., Silveira, C. E. S., Caldas, L. S. (1998), Coleta, propagação e desenvolvimento inicial de espécies do Cerrado. In Cerrado - Ambiente e flora. Ed Sano SM and Almeida SP. EMBRAPA - Brasília. pp. 195-243

Mercier, H., Souza, B. M., Kraus, J. E., Hamasaki, R. M., Sotta, B. (2003), Endogenous auxin and cytokinin contents associated with shoot formation in leaves of pineapple cultured in vitro. Braz. J. Plant Physiol., 15, 107-112.

Moffat, A. S. (2002), Brazilian ecosystems: history, management, and preservation: South American Landscapes: Ancient and Modern Sci., 296, 19591961.

Murashige, T., Skoog, F. (1962), A revised medium for rapid growth and bio assays with tobacco tissue cultures. Physiol Plantarum, 15, 473-497.

Nakagawa, H., Jiang, C-J., Sakakibara, H., Kojima, M., Honda, I., Ajisaka, H., Nishijima, T., Koshioka, M., Homma, T., Mander, L. N., Takatsuji, H. (2005), Overexpression of a petunia zinc-finger gene alters cytokinin metabolism and plant forms. Plant J., 41, 512-523.

Ndoye, M., Diallo, I., Gassama-Dia, Y. K. (2003), In vitro multiplication of the semi-arid forest tree, Balanites aegyptiaca (L.) Del. African J. Biotech., 2, 421-424.

Nuri, M. (2004), Inclusion of polyamines in the medium improves shoot elongation in hazelnut (Corylus avellana L.) micropropagation. Turk. J. Agric. Forest., 28, 189-194.

Pan, M. J., van Staden, J. (1998), the use of charcoal in in vitro culture - a review. Plant Growth Reg., 26, $155-163$ 
Pereira, A. M. S., Bertoni, B. W., Lopes, N. P. ; Paron, M. E., França, S. C., Amarante, V. S. (2005), In vitro propagation and germoplasm conservation of Lychnophora ericoides Mart: a medicinal species from the Brazilian cerrado. Rev. Fitos, 1, 69-73.

Perez-Tornero, O., Lopez, J. M., Egea, J., Burgos, L. (2000), Effect of basal media and growth regulators on the in vitro propagation of apricot (Prunus armenica L.) cv. Canino. J. Hort. Sci. Biotech., 3, 283-286 .

Pinto, J. E. B. P., Arello, E. F., Pinto, C. A. B. P., Barbosa, M. H. P. (1994), Uso de diferentes explantes e concentrações de benzilaminopurina na multiplicação in vitro de brotos de Kielmeyera coriaceae. Pesq. Agropec. Bras., 29, 867-873.

Quoirin, M., Silva, M. C., Martins, K. G., Oliveira, D. E. (2001), Multiplication of juvenile black wattle by microcuttings. Plant Cell Tissue Organ Cult., 66, 199205.

Rios, M. N. S., Ribeiro, J. F., Rezende, M. A. (2001), Propagação vegetativa: enraizamento em estacas de espécies nativas de Mata de Galeria. In: Ribeiro JF, Fonseca CEL, Sousa-Silva JC ed. Cerrado: caracterização e recuperação de matas de galeria. EMBRAPA - Brasília, pp. 455-467.

Siddique, N. A., Bari, M. A., Khatun, N., Rahman, M., Rahman, M. H., Huda, S. (2003), Plant regeneration from nodal segments derived callus in Hemidesmus indicus (L.) R. Br (Anantamul) an endangered medicinal plant in Bangladesh. J. Biol. Sci., 3, 11581163.

Silveira, C. E., Cottignies, A. (1994), Period of harvest, sprouting ability of cuttings, and in vitro plant regeneration in Fraxinus excelsior. Can. J. Bot., 72, 261-267.

Souza, F. C., Azevedo, F. A., Schinor, E. H., Filho, F. A. A. M., Mendes, B. M. J. (2005), Micropropagação de citrumelo 'swingle' pelo cultivo in vitro de gemas axilares. Rev. Bras. Frut., 27, 136-138

Souza-Silva, M., Ferreira, R. L. (2004), Heterotrophic succession in Alibertia edulis fruits: variation in resource availability and temporal heterogeneity of microhabitats for invertebrates. Ecotropica, 10, 2332.

Werner, T., Motyka, V., Laucou, V., Smets, R., Van Onckelen, H., Schmülling, T. (2003), Cytokinindeficient transgenic Arabidopsis plants show multiple developmental alterations indicating opposite functions of cytokinins in the regulation of shoot and root meristem activity. Plant Cell, 15, 2532-2550. 